\title{
Limity a perspektívy výkonu trestu odňatia slobody u dospelých odsúdených, v neštátnych ústavoch na výkon trestu odňatia slobody v Slovenskej republike, vzhladom na právne a mimoprávne záruky zákonnosti
}

Sergej Romža *

DOI: https://doi.org/10.24040/sap.2020.7.4.262-278

\begin{abstract}
Abstrakt:
ROMŽA, Sergej: Limity a perspektivy výkonu trestu odñatia slobody u dospelých odsúdených, $v$ neštátnych ústavoch na výkon trestu odñatia slobody v Slovenskej republike, vzhladom na právne a mimoprávne záruky zákonnosti. Privatizácia väzenského systému je predmetom širokospektrálnej diskusie odborníkov aj laikov, vo viacerých krajinách, pričom je vyvolaná pretrvávajúcimi problémami štátneho väzenského systému, spočívajúcich predovšetkým v preplnenosti väzníc a ekonomickej neefektívnosti ich prevádzky. Privatizácia väzenského systému, má svojich zarytých zástancov aj odporcov, ktorí vnímajú túto otázku skôr ideologicky ako pragmaticky. Súčasné modely privatizácie väzenského systému však umožňujú kompilovat' prvky štátneho a súkromného väzenského systému a tým aj optimalizovat' jeho fungovanie.
\end{abstract}

Kl'účové slová:

privatizácia väzenského systému; modely privatizácie; výkon trestu odňatia slobody; štátny väzenský systém; väznica;

\section{Limits and Perspectives of Imprisonment for Adult Convicts, in Private Institutions for Serving the Imprisonment in the Slovak Republic, with Regard to Legal and non-Legal Guarantees of Legality}

\footnotetext{
Abstract:

ROMŽA, Sergej: Limits and Perspectives of Imprisonment for Adult Convicts, in Private Institutions for Serving the Imprisonment in the Slovak Republic, with Regard to Legal and non-Legal Guarantees of Legality. The privatization of the prison system is the subject of a wide-ranging debate among experts and lay people alike, in several countries, and is caused by the persisting problems of the state prison system, consisting mainly in prison overcrowding and the economic inefficiency of their operation. The privatization of the prison system has its staunch supporters and opponents, who perceive the issue ideologically
}

prof. JUDr. Sergej Romža, PhD., Univerzita P.J.Šafárika v Košiciach, Právnická fakulta, vedúci Katedry trestného práva. Predložená štúdia vznikla s podporou a je výstupom riešenia výskumného projektu APVV-16-0362 „Privatizácia trestného práva - hmotnoprávne, procesnoprávne, kriminologické a organizačno-technické aspekty“. 
rather than pragmatically. However, current models of privatization of the prison system make it possible to compile elements of the state and private prison system and thus optimize its functioning.

\section{Key words:}

privatization of the prison system; privatization models; serving the imprisonment; state prison system; prison;

\section{Väzenstvo ako súčast’ trestnej politiky štátu - úvodné poznámky}

„Existuje jeden univerzálny zákon. Tým zákonom je spravodlivost'. Spravodlivost’ tvorí základný kameň práva každej krajiny" (Alex de Touqueville).

Spravodlivost', predstavuje absolútny imperatív, vo vzt'ahu ku všetkým ostatným princípom, na ktorých sú kreované jednotlivé právne poriadky a inak to nie je ani pokial' ide o trestné právo.

Prostriedkom na presadenie - implementáciu konceptu spravodlivosti do právnej praxe, do spoločenského života vo všeobecnosti, je trestná politika štátu. Okruh spoločenských vzt'ahov, ktorým sa má poskytnút' trestnoprávna ochrana a v akom rozsahu, a akým spôsobom, je elementárnou otázkou, ktorú si musí pokladat' a riešit' trestná politika štátu. ${ }^{2}$

Trestnú politiku štátu možno vo všeobecnosti charakterizovat' ako súbor politických, legislatívno-technických a organizačných opatrení, ktorých ciel'om je kreovat' ucelenú a dlhodobú koncepciu trestného práva, vrátane jednotlivých zásad a inštitútov, ktoré vytvárajú jej základ.

Trestná politika štátu vytvára ideový rámec d’alšieho smerovania trestnej politiky a trestného práva, ako prostriedku jej implementácie do aplikačnej praxe. Fázy a spôsoby implementácie trestnej politiky štátu, do aplikačnej praxe, sa odvíjajú od aktuálneho stavu spoločensko-ekonomických vzt’ahov, teda od požiadaviek a očakávaní odbornej a laickej verejnosti. Trestná politika štátu zároveň musí reflektovat' aj na medzinárodné záväzky, ktoré pre nás vyplývajú $\mathrm{v}$ oblasti trestného práva. $\mathrm{V}$ konečnom dôsledku trestná politika štátu musí reflektovat' aj na ústavou garantované základné práva a slobody.

Trestná politika štátu, by tak mala reflektovat' na súbor východísk historického, spoločensko-ekonomického, medzinárodnoprávneho a kriminogénneho charakteru, ale rovnako tak, by nemala opomínat' ani etické a morálne východiská. Rovnako trestná politika štátu, by mala reflektovat’ aj na vývoj doktrinálnych koncepcií v sociálnej oblasti, akými sú psychológia, sociálna práca, či psychiatria.

Základnou premisou trestnej politiky štátu je dôkladné poznanie existujúceho normatívneho stavu, poznanie (identifikácia) legislatívno-technických nedostatkov toho normatívneho stavu, a v neposlednom rade aj poznanie príčin, ktoré majú za

1 ROMŽA, S.: Koncepcia prípravného konania. Brno: Tribun EU, 2010, s. 7.

2 ROMŽA, S.: Význam spoločensko-ekonomických podmienok na formovanie trestnej politiky štátu. In: Trestná politika štátu, história, súčasnost'a perspektivy; Zborníkvedeckých príspevkovz Interdisciplinárnej celoštátnej vedeckej konferencie s medzinárodnou účastou. Košice: UPJŠ, 2015, s. 169. 
následok uvedené nedostatky a problémy.

Trestnú politiku štátu nemožno vnímat' a ani uplatňovat' ako statický, ale naopak dynamický fenomén, ktorý musí operatívne reflektovat' na aktuálnu spoločensko-ekonomickú situáciu, na nové fázy a prejavy kriminality, ale rovnako tak problémy súvisiace s praktickým uplatňovaním trestnej spravodlivosti v oblasti ukladania, ale predovšetkým výkonu trestných sankcií, osobitne výkonu trestu odňatia slobody.

Trestná politika štátov, nielen angloamerického, ale aj kontinentálneho právneho systému, je v posledných desatročiach poznamenaná presadzovaním nového trendu, ktorým je čoraz väčší prienik súkromného sektoru do verejnoprávnej sféry. $Z$ tradičného pohl'adu, je verejnoprávna sféra, práve tou oblast'ou spoločenského života, v ktorej majú výsostné postavenie orgány verejnej moci (štátne orgány). Ide predovšetkým o plnenie takých úloh štátnymi orgánmi, ako sú úlohy v oblasti ochrany bezpečnosti osôb a štátu, zachovávania verejného poriadku, či hospodárenia s finančnými prostriedkami štátu. Z tradičného pohl'adu, disponuje štát vo všetkých týchto oblastiach monopolom.

Čoraz častejšie však možno pozorovat' zaujímavý jav, ktorým je zverovanie verejnoprávnych oblastí, v ktorých má štát monopolné postavenie, do rúk súkromných osôb, do rúk rôznych podnikatel'ských subjektov. Tento fenomén je označený ako tzv. privatizácia verejného priestoru. ${ }^{3}$

V tejto súvislosti, pomerne diskutovanou otázkou je aj otázka eventuálnej privatizácie trestného konania, pod ktorou vo všeobecnosti možno rozumiet' oslabenie funkcii štátu v oblasti výkonu trestnej spravodlivosti a ich delimitovanie na subjekty, či procesné strany trestného konania, prípadne na súkromné subjekty, bez ohl'adu na ich právnu entitu, ktoré de lege lata stoja mimo rámec trestného konania. Fázy, či dokonca spôsoby praktickej realizácie, koncepcie privatizácie trestného konania, môžu nadobudnút' tak hmotnoprávny, procesný, či dokonca netrestný charakter.

Privatizácia trestného konania tak predstavuje trend, podstatu ktorého možno vidiet' $\mathrm{v}$ silnejšom zohl'adňovaní individuálnych záujmov, resp. $\mathrm{v}$ prístupe viac neformálne - súkromnom namiesto formálne-oficiálnom. ${ }^{4}$

Neuralgickou otázkou, privatizácie trestného konania, je otázka privatizácie $\mathrm{v}$ oblastiach, kde dochádza k obmedzovaniu, či dokonca pozbaveniu osobnej slobody, či už sú to zariadenia na umiestňovanie zadržaných osôb (tzn. cely policajného zaistenia), prípadne zariadenia na výkon väzby a trestu (ústavy na výkon väzby a trestu) alebo obmedzení, podl'a $\S 88$ Tr. por., prostredníctvom inštitútu zabezpečenia svedka.

Sumarizačne možno konštatovat', za cenu určitej abstrakcie a terminologickej nepresnosti, že ide o otázku tzv. privatizácie väzenstva (väzenského systému).

Privatizácia väzenského systému je trestnoprávnou jurisprudenciou definovaná ako „presun väzňov do zariadení prevádzkovaných súkromnými firmami na základe Zmluvy s orgánmi väzenskej správy, pričom predmetom tejto Zmluvy je výkon trestu nariadený odsúdenému súdnym orgánom, ktorý má byt’ uskutočňovaný vo väzení prevádzkovanom súkromnou firmou. " 5

3 ŠRÁMEL, B.: Privatizácia väzenského systému: áno alebo nie? In: Trestné právo, 2015, č. 1, s. 30.

4 ESSER,A.: Funchtinswandel strofrechtlicher Prozesmawimen: Auf dem Weg zur „Reprivotisierung“ des Strafverfahrens. In: Karl Krocschell recht und Venfahren: Symposium den recht\&swissen schaftlichen Fakultäten der Albert - Ludwigs - Universität Osaka, Heidelberg: Müller, 1993, s. 35.

5 JUNG, Y.: Prison privatization a perspective on core governmental functions. In: Crime, Law 
K uvedenému B. Šrámel dodáva, že „súkromnú firmu možno v tomto smere považovat' preto za akýsi nástroj štátu na uskutočňovanie nariadeného výkonu trestu odňatia slobody“ a zároveň poznamenáva, že „,na súkromnú firmu na základe Zmluvy prechádza iba povinnost' zabezpečit' výkon trestov odsúdených vo väzeniach, právna zodpovednost' zostáva stále v rukách štátu. "6

Opätovne sa žiada pripomenút', že privatizáciu väzenského systému nemožno nedôvodne redukovat' výlučne na privatizáciu výkonu trestu odňatia slobody, ale je namieste koncepciu privatizácie väzenského systému riešit' komplexne, teda vrátane privatizácie zariadení určených na umiestňovanie zaistených osôb, či už v režime podla $\S 17$ zákona č. 171/1993 Zb. o Policajnom zbore alebo v režime podl’a $\S 85$, resp. $\S 88$ Tr. por. Tento apel je namieste o to viac, že tieto zaist'ované osoby ešte neboli právoplatne odsúdené a nebol im ani nariadený výkon trestu odňatia slobody a dokonca voči nim nemusí byt' ani vedené trestné stíhanie (napr. v prípade zabezpečeného svedka, podl'a $\S 88 \mathrm{Tr}$. por.). Zároveň však sociálne podmienky v týchto zariadeniach (tzv. celách policajného zaistenia) nedosahujú štandardy Ústavov na výkon väzby a trestu odňatia slobody. Osobitne intenzívne tento handicap pocituje zaistený svedok a hádam aj preto súdy pristupujú k nariad'ovaniu zabezpečenia svedka, podl'a $\S 88$ Tr. por., vel'mi obozretne a zdržanlivo, dokonca aj v procesných situáciách, kedy sú naplnené všetky obligatórne procesné podmienky na takéto rozhodnutie, čo nepochybne negatívne vplýva na rýchlost', ale predovšetkým efektivitu trestného konania.

Z. Karabec podstatu privatizácie väzenského systému vidív tom, že štát uzatvára zmluvu so súkromnou firmou o tom, že táto súkromná firma zabezpečí a poskytne, pre účely výkonu trestu odňatia slobody určitého počtu odsúdených osôb, ubytovacie priestory. ${ }^{7}$

Pokial' ide o motiváciu štátu uvažovat' o zverenie väzenského systému do súkromnej oblasti, táto vychádza tak zo všeobecných, ako aj špeciálnych (špecifických) dôvodov.

Ako všeobecné dôvody sú najčastejšie uvádzané dôvody inštrumentálne a politické. Inštrumentálne dôvody privatizácie väzenstva sú spojené so snahou štátu dosiahnut', čo najvyššiu úroveň efektívnosti riadenia väzenského systému. To konkrétne znamená, že štát sa snaží dosiahnut' zlepšenie fungovania väzenského systému, za súčasného zníženia výdavkov na tento systém. Politické odôvodnenie privatizácie väzenského systému vychádza z ideologických východísk. ${ }^{8}$

Špecifickým dôvodom privatizácie väzenstva je predovšetkým nárast kriminality, ale predovšetkým nárast počtu osôb odsúdených na nepodmienečný trest odňatia slobody, a tým aj nárast počtu odsúdených vo väzenských zariadeniach (ústavoch na výkon väzby a trestu).

V období rokov 2015 - 2019 bolo vo výkone trestu odňatia slobody viac ako 10.000 odsúdených (väznených osôb). ${ }^{9}$ S vysokým počtom odsúdených vo výkone trestu odňatia slobody úzko súvisí aj preplnenost' väzenia, teda prekračovania uby-

and Social Change (2010) 54, s. 265.

6 ŠRÁMEL, B.: Privatizácia väzenského systému: áno alebo nie? In: Trestné právo, 2015, č. 1, s. 31.

7 KARABEC, Z.: Poznámky k trestní politice. In: Kriminalsitika č. 1/2012, s. 20.

8 JUNG, Y.: Prison privatization a perspective on core governmental functions. In: Crime, Law and Social Change (2010) 54, s. 264.

9 porov:: Ročenka Zboru väzenskej sa justičnej stráže za rok 2019, prístupné na http://www.zvjs. sk/dokumnety/rocenky/Rocenka2019. 
tovacej kapacity, čo nevyhnutne má svoje dôsledky aj pre bezpečnost' väzenia, čo vyvoláva synergický efekt zníženého sociálneho štandardu väzňov (odsúdených). Aktuálne je ubytovacia plocha $\mathrm{v}$ Ústavoch na výkon trestu odňatia slobody s minimálnym stupňom stráženia, na úrovni $2,88 \mathrm{~m}^{2},{ }^{10}$ pričom podl'a $\S 18$ ods. 1 zákona č. 475/2005, Z.z. o výkone trestu odňatia slobody a o zmene a doplnení niektorých zákonov v znení neskorších predpisov (d’alej len „Zo VTOS“) má byt' ubytovacia plocha $\mathrm{v}$ cele alebo izbe pre jedného odsúdeného minimálne $3,5 \mathrm{~m}^{2}$. Zákonodarca (štát), podl'a všetkých okolností, poznávajúc stav naplnenie väzníc, normatívne ukotvil v cit. $\S 18$ ods. 1, veta tretia Zo VTOS, exkulpačnú dočasnú výnimku z predpísaného ubytovacieho štandardu väzňov, podla ktorej ,ak sa nadmerne zvýši počet odsúdených v ústave, možno ubytovaciu plochu, na nevyhnutne potrebný čas znižit."“

Správne v tejto súvislosti pripomína a upozorňuje M. Štrkolec, že „,znižovanie ubytovacej plochy odsúdeného, by malo rešpektovat' princíp proporcionality zásahov do základných práv a slobôd odsúdených, ktorý je vlastný právnemu štátu a v zmysle ktorého možno dlhodobé nedosahovanie zákonom ustanovenej ubytovacej plochy pre jedného odsúdeného, v hypotetickej rovine označit' ako porušovanie princípu zákonnosti, ktorý predstavuje samotné jadro ústavnosti “. ${ }^{11}$

V tejto súvislosti a z uvedených dôvodov, bola uznesením vlády Slovenskej republiky č. 248/2011, v roku 2011, schválená Koncepcia väzenstva Slovenskej republiky na roky 2011 - 2020, ktorá ideovo vychádza z Programového vyhlásenia vlády, pričom vláda si stanovila za ciel': „reflektovat' potreby väzenstva a s týmto ciel'om stabilizovat' personálne zabezpečenie Zboru väzenskej a justičnej stráže, podl’a možnosti rozpočtu rozširovat' kapacity väzníc a usilovat' sa o posilnenie nástrojov reálnej prevýchovy odsúdených v rámci starostlivosti o odsúdených počas výkonu trestu odñatia slobody “. ${ }^{12}$

\section{Historické súvislosti vzniku a vývoja koncepcie privatizácie väzenského systému v premenách času}

Prvotné úvahy a koncepcie privatizácie väzenského systému možno spol'ahlivo zaznamenat' ešte $\mathrm{v}$ období 19. storočia $\mathrm{v}$ Taliansku, a to $\mathrm{v}$ súvislosti so vznikom potreby výmeny poznatkov a skúseností sudcov a väzenských pracovníkov s trestaním „,previnilcov“ a s uplatňovaním vhodných penologických systémov, čo vyvolalo vlnu reformného hnutia v oblasti trestného súdnictva a výkonu trestov aj v celej západnej Európe. Tieto reformné zmeny sa až následne preniesli aj na americký kontinent, kde sa v modifikovaných podobách uplatňovali dokonca vo väčšom rozsahu ako v samotnej Európe. ${ }^{13}$

10 porov:: Aktuálna ubytovacia plocha v m² , Príloha č. 5 ku Koncepcii väzenstva Slovenskej republiky na roky 2011-2020, prístupné na:

http://www.rokovania.sk/File.aspx/ViewDocumentHtm/MaterDokum - 175978?prefixFile.

11 ŠTRKOLEC, M.: Väzenstvo Slovenskej republiky - vybrané problémy súčasnosti a perspektívy do budúcnosti, In: Trestná politika štátu, história, súčasnost’a perspektívy; Zborník vedeckých príspevkov z Interdisciplinárnej celoštátnej vedeckej konferencie s medzinárodnou účastou. Košice: UPJŠ, 2015, s. 306.

12 Porov. Koncepcia väzenstva Slovenskej republikyna roky 2011-2020. Aktualizácia, s. 5, prístupné na : http://www.rokovania.sk/Rokovania.aspx/BodRokovaniaDetail?id Materiál=22614.

13 VÁLKOVÁ, H. - KUCHTA, J. a kol.: Základy kriminológie a trestní politiky. 2. vydání, Praha: 
Trestnoprávna jurisprudencia zaznáva v novodobej histórii USA, dve historické etapy fungovania privatizovaných väzení. Prvá etapa existencie súkromných väzení, v novodobej histórii USA, je datovaná do roku $1840-1960 .{ }^{14}$ Celá prvá éra súkromného väzenstva bola poznamenaná v USA, obzvlášt' obdobie druhej polovice 19. storočia, masívnym využívaním väzenskej práve, s čím bol spojený aj prenájom väzňov na prácu. Súkromné firmy prevzali zodpovednost' za starostlivost', ubytovanie a bezpečnost' väzňov, za čo im štát platil určitú finančnú odmenu. Súčasne štát reálne znížil svoje náklady na prevádzkovanie väzenského systému. ${ }^{15}$

Koniec prvej etapy fungovania súkromných väzení v USA, na začiatku druhej polovice 20. storočia súvisel s viacerými faktormi, medzi inými aj škandálmi so zneužívaním práce väzňov, zníženým dopytom po práci väzňov a v konečnom dôsledku aj s novou generáciou politikov a väzenských funkcionárov. ${ }^{16}$ Nástup druhého obdobia (etapy) súkromných väzení v USA, spadá do polovice osemdesiatych rokov 20. storočia, ked'v roku 1984, americká väzenská spoločnost' (CCA - Corrections Corporation of America) začala prevádzkovat' prvé väzenie, po vel'mi dlhom období, úplne v rukách súkromného subjektu. Následne, d'alšie desat'ročia boli v znamení nárastu počtu súkromných väzení. Samozrejme aj „,reprivatizácia“ väzení v USA je sprevádzaná viacerými negatívnymi javmi, ktorých signifikantným znakom je uplatňovanie a presadzovanie trhových pravidiel do prevádzky súkromných väzení, a to za každú cenu, teda niekedy aj na úkor účelu sledovaného výkonom trestu odňatia slobody teda predovšetkým resocializácie väzňov (odsúdených), čo je v mnohých prípadoch potvrdzované aj na zákonnej a ústavnej úrovni.

$\mathrm{V}$ súvislosti $\mathrm{s}$ historickým kontextom vzniku a existencie súkromného väzenského systému, OGLE, R.S., poznamenáva „,̌e história súkromných väzení odráža mylnú predstavu, že zavedením trhového mechanizmu do väzenského systému, možno dosiahnut' jeho plnú funkčnost', bez porušovania základných inštitucionálnych princípov jeho fungovania“. K uvedenému d’alej poznamenáva, že „história ukázala, že práve naopak, tento princíp viedol ku koncepcii zneuživania odsúdených, politickej manipulácii a v konečnom dôsledku $k$ zlyhaniu súkromného väzenského systému. Súkromné väzenské kooperácie, podla jeho názoru, totiž neboli pasívnymi entitami, ale agresívnymi trhovými hráčmi.“" 17

$\mathrm{K}$ uvedenému sa žiada poznamenat, že prezentovaný kritický postoj k negatívnym javom sprevádzajúcich súkromný väzenský systém, je v mnohých smeroch absolútne namieste, na strane druhej však vytvára mylnú predstavu a dojem, že štát ako prevádzkovatel' väzenského systému, je ideálnym riešením a zároveň aj efektívnejším riešením spôsobu výkonu trestu odňatia slobody a že s prevádzkovaním štátnych väzení nie sú spojené žiadne praktické problémy. Opak je pravdou, ked’ sme pomerne

C.H.BECK, 2012, s. 238.

14 JUNG, Y.: Prison privatization a perspective on core governmental functions. In: Crime, Law and Social Change (2010) 54, s. 264.

15 PILCHER, D.: State Correctional Industries: Choosing Goals, Accepting Tredeoffs, Denver, Vo: National Conference of State Legislatures, June 1989, s. 12.

16 DI LULIO, J.J.: What'swrong with Private Prisons. In: Public Interest, Summer 1988, 92, s. 73.

17 OGLE, R., S.: Prison privatization. An Enviromental Cater - 22. In: Justice Quarberly. Vol. 16. No 3 (199), s. 590. 
často svedkami porušovania väzenských pravidiel príslušníkmi Zboru väzenskej a justičnej stráže, a to tak závažného charakteru, že sú voči ním vyvodené trestnoprávne konzekvencie. Zároveň, v súčasnosti nebol zrealizovaný seriózny ekonomický audit efektivity fungovania štátnych väzení, teda či finančné náklady ich prevádzky, na jedného väzňa, korelujú hospodárnemu a účelnému vynakladaniu verejných zdrojov.

Uvedenými (ekonomickými) aspektmi fungovania štátnych väzenských systémov sa v slovenských podmienkach nevenujú, resp. nevenujú seriózne žiadne kompetentné autority, a to vrátane Najvyššieho kontrolného úradu, ktorý maximálne posudzuje, pokial' vôbec, to, či vynaložené verejné zdroje boli použité na deklarovaný účel, nie však to, či boli použité aj efektívne a hospodárne, $v$ snahe minimalizovat' a optimalizovat' prevádzkové náklady. Požiadavka na ekonomický audit efektivity hospodárenia štátnych väzení je však len prvým krokom a zároveň materiálnym predpokladom na komplexné, korektné a zároveň kvalifikované zhodnotenie fungovania štátnych väzení, s ktorým musí byt' spojené aj zhodnotenie právne, sociálne a penitenciárne hl'adiská naplnenia účelu, ktorý je inak sledovaný nariadeným výkonom trestu odňatia slobody. Osobitne citlivo, je potrebné v tejto súvislosti vyhodnocovat' fenomenológiu kriminálnej recidívy, ako aj vlastnej miery efektivity resocializácie páchatel'ov. Takéto komplexné a komparatívne zhodnotenie (podla porovnatel'ných, ak nie identických referenčných parametrov) tak štátneho, ako aj súkromného väzenského systému v podmienkach Slovenskej republiky, z objektívnych dôvodov (neexistencia súkromných väzníc), nebolo zrealizované a nebolo podl'a všetkého zrealizované ani v zahraničí, aj ked' parciálne pokusy boli zaznamenané (Mad’arská republika), avšak išlo o hodnotenie, ktoré sa týkalo len vybraných aspektov výkonu trestu odňatia slobody v týchto zariadeniach, a preto nemajú zásadnú validitu pre zásadné závery o výhodnosti, či nevýhodnosti toho - ktorého väzenského systému. Jednoducho v súčasnosti nie je vypracovaná jednotná metodika (pravidlá) tak na národnej, ako aj na medzinárodnej úrovni, ktorá by umožňovala komplexne, korektne, kvalifikovane a komparatívne vyhodnotit' jednotlivé parametre fungovania tak štátneho, ako aj súkromného väzenského systému. Nepochybne aj táto skutočnost', negatívne ovplyvňuje úvahy jednotlivých národných štátov zavádzat' - implementovat' súkromné väzenia či aspoň niektoré jeho symptómy, do fungovania väzenského systému. Prístup exekutívy USA, $\mathrm{k}$ fungovaniu súkromného väzenského systému, len potvrdzuje prezentované premisy a zistenia, ked' tento sa vyznačuje tzv. mantinelizmom, teda od jedného extrému k druhému, od velebenia až po zatracovanie súkromného väzenského systému. Kým prezident B. Obama vehementne kritizoval súkromné väznice ako neefektívne a drahé, potom, súčasný prezident $\mathrm{D}$. Trump, nedá na súkromné väzenia dopustit'. V USA sa preto privatizácia väzníc v 90. rokoch a v súčasnosti zintenzívnila, pričom v súčasnosti sa súkromné firmy podiel’ajú na výkone trestu odňatia slobody $19 \%$ väzňov v krajine. Vláda USA, súkromným spoločnostiam, ktoré participujú na prevádzkovaní väzníc, poskytuje finančnú dotáciu 23.000 dolárov na každého väzňa, a to napriek tomu, že minimálna mzda je v USA iba 15.000 dolárov ročne. ${ }^{18}$. Obrat hlavných spoločností, ktoré prevádzkujú súkromné väznice, v posledných rokoch, výrazne vzrástol. Je teda možné generalizovat', že americ-

18 LA JORNADA: Americký Gulag je výnosný byznys ! První zprávy.cz.(online), 3.10.2019(cit. 2019-10-22). Dostupné na: http://www.prvnizpravy.cz (zpravy) la-jornada-americky-gulagjevynosny-byznys. 
ký súkromný väzenský systém (priemysel), má ročné príjmy, vo výške 5 miliárd dolárov. ${ }^{19}$

Podl'a J. Oades, USA sa síce naučili na väzenstve zarábat', ale nenaučili sa ich robit' efektívnymi. ${ }^{20}$

Referovaný aktuálny stav väzenského systému v USA svedčí o tom, že z ekonomického hladiska, môže byt' súkromný väzenský systém efektívny, nič na veci nemení skutočnost', že priemerné náklady na jedného väzňa sú vy̌šsie ako je minimálna mzda v USA, nakol'ko ide o kategórie, ktoré majú výpovednú hodnotu len vo vzt'ahu $\mathrm{k}$, ,ušlému zisku“ šstátu u väzňa, ktorý nepracuje, ale je vo výkone trestu odňatia slobody. Predmetný ukazovatel' (komparácia) však nemá žiadnu výpovednú hodnotu, vo vzt'ahu k efektivite vynaložených finančných prostriedkov na jedného väzňa, teda či súkromné väznice majú nižšie finančné náklady na jedného väzňa, ako štátne väznice. Práve prezentovaný záver J. Oades, svedčí o tom, že podl'a všetkých okolností, komparácia ekonomickej efektivity výkonu trestu odňatia slobody v súkromných a štátnych väzenských zariadeniach, vychádza v prospech súkromných väzenských zariadení. Inou, nezodpovedanou otázkou, je efektivita penitenciárna, sociálna a trestnoprávna.

Privatizáciu väzenstva však nemožno teritoriálne obmedzovat' len na USA aj ked' tieto v otázke prevádzkovania súkromných väzenských zariadení, majú najväčšie skúsenosti. Snahy o privatizáciu väzenstva možno zaznamenat' aj v Austrálii, Juhoafrickej republike, na Novom Zélande, či Vel'kej Británii, ale rovnako tak v krajinách Európskej únie. Konkrétne ide o Francúzsko, Belgicko, Estónsko, či susedné Mad'arsko. Je potrebné v tejto súvislosti poznamenat', že každá z týchto krajín pristupuje $\mathrm{k}$ implementácii súkromných prvkov do väzenského systému iným spôsobom. Vel'ká Británia zverila súkromnému sektoru väčšinu exekutívnych kompetencii súvisiacich s výkonom trestu odňatia slobody, konkrétne stráženie väzňov, správu väzníc, zodpovednost' za resocializáciu väzňov, ich predvádzanie, či eskortovanie. Štátna správa vo Vel'kej Británii vykonáva výlučne dohl'ad nad dodržiavaním zákonných podmienok výkonu trestu, vrátane dodržiavania dohodnutých obligačných podmienok výkonu trestu, vrátane dodržiavania dohodnutých obligačných podmienok súkromným partnerom súvisiacich so správou väznice. ${ }^{21}$

Pre Slovenskú republiku sa javí nepochybne inšpiratívnou snaha o privatizáciu väzenstva v Č eskej republike, kde seriózne diskusie na túto tému začali v roku 1997, kedy bol pripravovaný aj nový zákon o výkone trestu odňatia slobody. ${ }^{22}$

Pre zapojenie súkromného sektora do procesu výkonu trestu odňatia slobody je kl'účové ust. § 13 zákona č. 169/1999 Sb. o výkonu trestu odnětí svobody (d’alej len „ZVTOS“), ktoré priznáva Ministrovi spravodlivosti kompetenciu zriadit’ väznicu aj v inom objekte, ako je objekt v správe väzenskej služby. Podmienkou je súhlas vlastníka tohto objektu a uzatvorenie Zmluvy o zriadení vecného bremena. Zákon d’alej stanovuje, že objekt, v ktorom je väznica zriadená, spravuje a prevádzkuje vlastník

19 Tamtiež.

20 KUČERA, V.: Evropské väzenské systémy. In: Právné rozhledy, 2002, č. 11, s. 577.

21 TLAPÁK - NAVRÁTILOVÁ, J.: Má privatizace vězeňství budoucnost? In: Kriminologické a organizačno-technické aspekty privatizácie trestného práva, Zborník príspevkov z medzinárodnej vedeckej konferencie III. Košické dni trestného práva, Košice: UPJŠ, 209, s. 163.

22 MIKULEC, V. - NOVOTNÝ, O.: Vězentví a právo. In: Verejná správa a právo: pocta prof. JUDr. Dušanu Hendrychovi k 70. narozeninám. Praha: C.H.BECK, 1997, s. 221. 
objektu, na základe zmluvy uzatvorenej s väzenskou správou. Väzenská správa však zodpovedá za stráženie, zaobchádzanie s odsúdenými a za dodržiavanie zákonných podmienok výkonu trestu. V tejto súvislosti sa Tlapák - Navrátilová, J., zamýšl’a nad tým, či je možné za týchto okolností, zverit' výkon týchto činností aj inému subjektu ako vlastníkovi budovy, pričom dospela k záveru, že ,,napriek tomu, že § 13 o ZVTOS hovorí iba o vlastnikovi objektu, je potrebné predmetné ustanovenie vykladat' tak, že v určitých prípadoch, by malo byt' možné zverit' výkon týchto činností aj inému subjektu. Dôvodom je predovšetkým účel tohto ustanovenia, ktorým je umožnenie zverenia výkonu $v$ týchto činnosti tretej osobe “. ${ }^{23}$. V Českej republike, na konci roku 2018, odštartoval nový typ spolupráce medzi štátnym a súkromným sektorom podpisom Zmluvy o práve stavby a Koncesnej zmluvy na výstavbu a prevádzku výrobnej haly, ktorú medzi sebou uzatvorili zástupcovi Väzenskej služby a Väznice Plzeň a súkromnej spoločnosti. ${ }^{24}$

\section{Modely privatizovaného väzenského systému (výkon trestu odňatia slobody)}

CHi, K.S., rozoznáva pät’ základných modelov fungovania privatizovaného väzenského systému:

1. model súkromných služieb (private services model);

2. model súkromnej výstavby (private construction model);

3. model súkromného riadenia (private managment model);

4. model prevzatia súkromnou firmou (private takeover model);

5. model súkromného vlastníctva a prevádzkovania (private ownership and operation model); ${ }^{25}$

Uplatnená klasifikácia jednotlivých modelov fungovania privatizovaného väzenského systému, sa odvíja od spôsobu a rozsahu intervencie súkromného sektora pri prevádzkovaní a riadení jednotlivých činností (aktivít) spojených s výkonom trestu odňatia slobody.

Ad 1.) model súkromných služieb spočíva $\mathrm{v}$ tom, že štát uzatvára zmluvu so súkromnou firmou, za účelom poskytovania výbraných služieb v ústavoch na výkon trestu odňatia slobody. Medzi takéto služby patrí zabezpečovanie práce pre väzňov, zabezpečovanie zdravotnej starostlivosti pre väzňov, zabezpečenie vzdelávania pre väzňov, zber a likvidácia odpadu vo väzení, eskorta väzňov. Tento model patrí k najstarším modelom a zároveň k najvýznamnejším modelom privatizovaného väzenského systému a súčasne aj k najmenej kontroverzným modelom. ${ }^{26 .}$ Tento model vychádza zo správnej pre-

23 TLAPÁK - NAVRÁTILOVÁ, J.: Má privatizace vězeňství budoucnost ? In: Kriminologické $a$ organizačno-technické aspekty privatizácie trestného práva, Zborník príspevkov z medzinárodnej vedeckej konferencie III. Košické dni trestného práva, Košice: UPJŠ, 209, s. 161-162.

24 NAVRÁTIL, P.: Konec nudy ve věznicích? Vězni nastoupí do práce. In: Globe24.cz(online). 20.12.2018 cit. 2019-10-22). Dostupné na : https://globe24.cz.domov(65023-konce-nudy-veveznicich-vezni-nastoupi-do-prace.

25 CHI, K. S.: Prison Overcrowding and Privation. Models and Opportunites. In: The journal of State Govermment, Mar/Apr, 1989, 62, 2 s. 70.

26 ZAGER, M.A. - McGAMA, J. - GARCIA, L.: Prison Privatization and Public Budgeting: A Meta - analysis of the Literature. In: Journal of Public Budgeting Accounting and Financial 
misy, že určité služby majú a priori súkromný charakter, a teda bežne sa poskytujú (sú rozšírené) aj v civilnom živote a zároveň poskytovanie týchto služieb pre väznice nevykazuje také zásadné špecifiká, pre ktoré by ich výkon musel byt' realizovaný štátom. Jednoducho, úlohou štátu nie je primárne podnikat' v jednotlivých oblastiach, a preto využívanie služieb súkromného sektora, osobitne špeciálnych služieb, je obojstranne prospešné, samozrejme pri nastavení obvyklých a korektných obligačných podmienok.

Ad. 2) model súkromnej výstavby, je založený na tom, že súkromná firma vybuduje ústav výkonu trestu odňatia slobody. ${ }^{27}$ Tento model je funkčný a nie je vnímaný kontroverzne pokial' výstavba väznice nie je následne kombinovaná s d’alšími modelmi (formami) spolupráce, s čím majú negatívne skúsenosti predovšetkým v Mad’arsku, kedy výstavba väznice bola kombinovaná s jej nasledovným prevádzkovaním súkromnou spoločnost'ou, s možnost'ou štátu po určitom čase odkúpit' túto väznicu. Pravdou je, že problém nebol ani v samotnej kombinácii jednotlivých foriem (modelov) spolupráce so súkromným sektorom, ale v nastavení finančných (ekonomických) podmienok (parametrov) tejto spolupráce, ked' možnost' štátu odkúpit' väznicu bola dohodnutá na obdobie, po ktorom sa súkromnému zhotovitel’ovi tejto väznice, náklady na jej obstaranie (vybudovanie) vrátili niekol'ko násobne a navyše ani samotná kúpna cena, po skončení obdobia nájmu väznice nebola obvyklá trhovým podmienkam. Tento príklad ilustruje skôr individuálne zlyhanie zodpovedných zástupcov štátu, ktorí pristúpili na jednostranne nevýhodné podmienky súkromného partnerstva. Jednoducho tento prípad nemožno označit' ako systémové zlyhanie štátneho a súkromného partnerstva.

Ad. 3) model súkromného riadenia, spočíva v tom, že štát vybuduje väzenie, štát zostáva jeho vlastníkom, avšak väzenie je prevádzkované súkromnou spoločnost'ou. Ide o určitú formu manažérskeho riadenia väzenia súkromnou firmou.

Ad. 4) model prevzatia súkromnou firmou, spočíva v tom, že súkromná firma prevezme celé štátne väzenie, a to na základe uzatvorenej Zmluvy o prenájme a riadení. Súkromná firma tu preberá výkon väčšiny funkcií štátneho väzenia. Na rozdiel od predchádzajúceho modelu súkromná firma preberá od štátu nielen riadenie (manažérske), ale rovnako tak aj jeho prevádzkovanie. Štát $\mathrm{v}$ tomto prípade zodpovedá za plánovanie, kontrolu a hodnotenie väzenských programov realizovaných súkromnou firmou. ${ }^{28}$

Ad. 5) model súkromného vlastníctva a prevádzkovania, spočíva v tom, že súkromná firma vlastní, riadi a prevádzkuje väzenie. Na rozdiel od predchádzajúceho modelu, súkromná firma nielen riadi a prevádzkuje, ale rovnako tak vlastní väzenie. V podstate ide o ,absolútnu“ formu privatizácie väzenského systému, ktorého ciel’om je pomerne rýchlo, finančne efektívne riešit' stav preplnenosti väzníc, ale ani pri tomto modeli sa štát nezbavuje dohl'adu nad dodržiavaním zákonných podmienok

Managment, Summer 2001, 13, 2, s. 226.

27 CHI, K. S.: Prison Overcrowding and Privation. Models and Opportunites. In: The journal of State Govermment, Mar/Apr, 1989, 62, 2 s. 71.

28 CHI, K. S.: Prison Overcrowding and Privation. Models and Opportunites. In: The journal of State Govermment, Mar/Apr, 1989, 62, 2 s. 72. 
výkonu trestu odňatia slobody. Okrem toho výhodou tohto modelu sú rôzne daňové zvýhodnenia, či finančné stimuly. ${ }^{29} \mathrm{~V}$ uvedenom smere ide pre súkromné firmy o najpopulárnejší model, ktorý umožňuje súkromnej firme nastavit' a optimalizovat' fungovanie finančných tokov ako aj personálnych kapacít využívaných na riadenie a prevádzkovanie väzenia.

Sumarizačne možno konštatovat', že u modelov privatizovaného väzenského systému, ktoré sú založené aj na prevádzkovaní väzenia, hospodárenie súkromných väzení vychádza $\mathrm{z}$ vyčíslenia nákladov na 1 lôžko/1 deň. Výhodou tohto systému je určitá miera istoty pre súkromnú firmu, že štát si objedná určitý fixný počet lôžok na určitú dobu (napr. 3 - 4 roky), čo umožňuje súkromnej firme v dostatočnom časovom horizonte projektovat' svoje podnikatel'ské aktivity. Štát obvykle v týchto prípadoch platí aj za lôžka, ktoré neobsadí. ${ }^{30}$

\section{Medzinárodné a ústavné východiská (limity) výkonu trestu odňatia slobody}

Ochrana práv odsúdených (väzňov), je predmetnom normatívnej úpravy obsiahnutej vo viacerých medzinárodných dokumentoch.

Predovšetkým túto reglementáciu nachádzame v dokumentoch ktoré prijalo OSN. Konkrétne Hospodárska ekonomická rada a jej Výbor pre prevenciu a kontrolu kriminality, prijali Štandardné minimálne pravidlá OSN pre zaobchádzanie s väzňami (Standard Minimum Rules for the Treatment of Prisoners - UN SMR), ktoré boli vydané vo forme odporúčaní všetkým vládam členských štátov OSN, aby tieto boli rešpektované pri zákonnej a inej normatívnej úprave väzenstva. ${ }^{31}$

Predmetný dokument obsahuje minimálne pravidlá - štandardy pre využívanie nástrojov, prostredníctvom ktorých dochádza k obmedzovaniu osobnej slobody vo väzniciach. Možno teda konštatovat', že predmetný dokument obsahuje a stanovuje univerzálne pravidlá výkonu trestu odňatia slobody, bez ohl'adu na prípadné regionálne špecifiká.

V európskom priestore ideovo a vecne, nadväzujú na označené Štandardné minimálne pravidlá OSN pre zaobchádzanie s väzňami, Európske väzenské pravidlá, ktoré sú ich prepracovanou (dopracovanou) verziou, pričom sú aktualizované na regionálne podmienky - európske tradície, kultúrne hodnoty a nové stratégie väzenstva. Európske väzenské pravidlá boli prvý krát vyhlásené rezolúciou Rady Európy (73) 5, v roku 1973, pod názvom (European) Standard Minimum Rules for the Treatment of Prisoners.

V prepracovanej verzii boli potom v roku 1987 tieto pravidlá označené ako European prison rules (EPR), na základe odporúčania Výboru ministrov Rady Európy ako rezolúcie č. (87) 3, ktoré boli postupne implementované do právnych poriadkov jednotlivých členských štátov EÚ.

Kl'účovým aspektom, v týchto Európskych väzenských pravidlách, je zachovanie

29 CHI, K. S.: Prison Overcrowding and Privation. Models and Opportunites. In: The journal of State Govermment, Mar/Apr, 1989, 62, 2 s. 72.

30 KARABEC, Z.: Poznámky k trestní politice. In: Kriminalistika č. 1/2012, s. 20.

31 FLEGL, V.: Minimální standardní pravidlá pro zacházení s vězněnými osobami. In: Medzinárodní ochrana spravedlnosti a lidskosti (Dokumenty OSN); Praha: SPEKTRUM; 1990. 
(rešpektovanie) l'udskej dôstojnosti väzňov.

Európske väzenské pravidlá, nakoniec boli aktualizované a prepracované na základe Odporúčania Ree (2006) 2 Výboru ministrov Rady Európy. Aktualizácia sa týkala predovšetkým ukotvenia (odporúčania) práva väzňov na prístup k adekvátnej právnej pomoci. Medzi d'alšie dokumenty upravujúce podmienky výkonu trestu odňatia slobody, nepochybne patrí Európsky dohovor pre prevenciu mučenia a nel'udského alebo degradujúceho zaobchádzania (1987), ktorý bol prijatý orgánom Rady Európy. Európsky výbor pre prevenciu mučenia a neludského alebo degradujúceho zaobchádzania alebo trestania, známy aj pod skratkou CPT (European Committee for Prevention of Torture and Inhuman or Degrading Treatment or Punishment).

Hádam najvýznamnejším medzinárodným dokumentom, ktorý upravuje základné práva a slobody osôb, ktoré sú vo výkone trestu odňatia slobody, je Dohovor o ochrane l'udských práv a základných slobôd (d'alej len ako „DOLP a a ZS“).

Predmetný dokument poskytuje aj osobám, ktoré sú odsúdené a sú vo výkone trestu odňatia slobody, viaceré procesné práva, ktoré možno označit' ako základné práva a slobody.

Normatívna úprava týchto základných práv a slobôd odsúdených osôb, je koncentrovaná vo viacerých ustanoveniach DOL'P a ZS. Konkrétne čl. 3 DOLP a ZS, zakazuje mučenie, nel'udské zaobchádzanie a trestanie, ako aj ponižujúce zaobchádzanie a trestanie.

Tento zákaz vychádza z nevyhnutnosti zachovania fyzickej a psychickej integrity človeka, ktorá je predpokladom jeho humánneho zakotvenia v spoločnosti. Spolu s právom na život a osobnou slobodou patrí k základným a prirodzeným právam človeka. ${ }^{32}$

Rovnako čl. 5 DOLP a ZS, garantuje odsúdenému, právo na slobodu a bezpečnost'. Dôvody pozbavenia osobnej slobody sú taxatívne vymedzené v čl. 5 ods. 1 , pričom jedným z týchto legálnych a legitímnych dôvodov je aj zákonné uväznenie po odsúdení príslušným súdom. Z dikcie čl. 5 ods. 1 písm. a) DOLP a ZS teda vyplýva, že tieto dôvody a podmienky pozbavenia osobnej slobody, musia byt' zákonné a vykonané na základe interných normatívnych aktov.

V neposlednom rade, čl. 6 ods. 1 DOLP a $Z S$, garantuje aj odsúdenému, ktorý je vo výkone trestu odñatia slobody, právo na spravodlivý súdny proces. Obsahom tohto práva je totiž právo na vymožitel'nost' práva.

Integrálnou súčast'ou práva na spravodlivý súdny proces, podl’a čl. 6 ods. 1 DOL’P a ZS je aj právo na prístup súdu, ktorého podstatou je poskytnutie možnosti každému, koho práva sú ukrátené, aby ich mohol uplatnit' na súde. Právo na prístup na súd, vyžaduje od štátu, aby nevytváral akékolvvek, či už formálne (napr. zákonné) alebo faktické prekážky prístupu, na súd. ${ }^{33}$ Súčast'ou tohto práva a tomu korelujúcej povinnosti, nevytvárat' procesnoprávne podmienky stažujúce prístup na súd, sú aj podmienky potrebné na začatie konania. Integrálnou súčast’ou (atribútom) tohto práva, je potom aj zákaz vyčleňovat' určité skupiny osôb z možnosti prístupu na súd, a to vrátane osôb vo výkone trestu odňatia slobody.

Na základné práva a slobody odsúdeného garantované referovanými ust. čl. 3, 5

32 SVÁK, J.: Ochrana l’udských práv (z ohladu judikatúry a doktriny štrasburských orgánov práv). Bratislava: EURO KÓDEX, 2003, s. 163.

33 Tamtiež, s. 284. 
ods. 1 písm. a), ako aj čl. 6 ods. 1 DOL'P a ZS, ideovo a vecne nadväzuje aj čl. 13 DOL'P $\boldsymbol{a} \boldsymbol{Z S}$, ktorý odsúdenému, ktorý je vo výkone trestu odňatia slobody, garantuje právo na účinný prostriedok nápravy, podl'a ktorého „každý, koho práva a slobody priznané týmto Dohovorom boli porušené, musí mat' účinné právne prostriedky nápravy pred národným orgánom, aj ked'sa porušenia dopustili osoby pri plnení úradných povinnosti “.

$\mathrm{Na}$ normatívnu reglementáciu limitov výkonu trestu odňatia slobody ukotvenú v medzinárodných dokumentoch ideovo nadväzuje reglementácia na ústavnej úrovni, ktorá je konkrétne normatívne ukotvená v č. 13 ods. 1, 4 Ústavy a nadväzne aj v čl. 16 ods. 2 čl. 17 ods. 2 Ústavy Slovenskej republiky.

Podl'a čl. 13 ods. 1 písm. a) Ústavy SR ,povinnosti možno ukladat' zákonom alebo na základe zákona, v jeho medziach a pri zachovaní základných práv a slobôd.“

Podl'a čl. 13 ods. 2 Ústavy SR ,medze základných práv a slobôd možno upravit’ za podmienok ustanovených touto ústavou len zákonom.“

Podl'a čl. 13 ods. 4 Ústavy SR ,pri obmedzovaní základných práv a slobôd sa musí dbat' na ich podstatu a zmysel. Takéto obmedzenia sa môže použit' len na ustanovený ciel'.“

Podl'a čl. 16 ods. 2 Ústavy SR „nikoho nemožno mučit’ ani podrobit' krutému, neludskému, či ponižujúcemu zaobchádzaniu alebo trestu. "

Podl'a čl. 17 ods. 2 Ústavy SR ,nikoho nemožno stíhat' alebo pozbavit' slobody inak, ako z dôvodov a spôsobom, ktorý ustanoví zákon."

K normatívnym podmienkam a limitom obmedzenia základných práv a slobôd občanov, pomerne presne a výstižne zaujal stanovisko Ústavný súd Slovenskej republiky (d’alej len „ÚS SR“), ked’ judikoval, že „pokial’ ide o realizáciu ústavného prikazu povinnosti ukladat' zákonom alebo na základe zákona, v jeho medziach a pri zachovani základných práv a slobôd vyplývajúcich z čl. 13 ods. 1 písm. a) Ústavy, nemôže byt' vo všeobecne záväznom nariadeni uložená nová povinnost', ktorá neexistuje $v$ zákone. Nerešpektovanie uvedeného príkazu Ústavy, by znamenalo negáciu zvrchovanosti zákona, a tým popretie samotného princípu právneho štátu. “34

Ústava SR výslovne určuje podmienky, ktoré legitimizujú obmedzenia základného práva alebo slobody. Podmienky obmedzenia základného práva alebo slobody ustanovuje čl. 13 ods. 2 - 4. Účelom úpravy čl. 13 ods. 2 je určit' formálnu záruku obmedzenia základných práv a slobôd. Materiálne podmienky obmedzenia základných práv, resp. slobôd sú implikované v čl. 13 ods. ${ }^{\longleftarrow}$ a ¿ Ústavy SR. ${ }^{35}$

\section{Zákonné limity (východiská) výkonu trestu odňatia slobody}

Normatívna úprava podmienok výkonu trestu odňatia slobody v Slovenskej republike je obsiahnutá vo viacerých normatívnych prameňoch rôznej právnej sily, a teda aj záväznosti.

V̌̌eobecná normatívna úprava podmienok výkonu trestu odn̆atia slobody je

34 Porov. II. ÚS 100/02. Nález z 30. januára 2003. Zbierka nálezov a uznesení Ústavného súdu Slovenskej republiky 2003 - I. polrok. s. 65.

35 DRGONEC, J.: Ústava Slovenskej republiky, komentár, Šamorín: Heuréka, 2007, s. 159. 
systémovo inkorporovaná do obsahu štvrtej časti, prvej hlavy Trestného poriadku ( $\S$ 406 a nasl.). V Trestnom poriadku je obsiahnutá predovšetkým normatívna úprava podmienok nariad’ovania výkonu trestu ( $\$ 408$ Tr. po.), odkladu výkonu trestu ( $\$ 407$ Tr. por.), rozhodovania o zmene spôsobu výkonu trestu ( $\$ 411$ Tr. por.), prerušenie výkonu trestu ( $\$ 412$ Tr. por.), upustenia od výkonu trestu ( $\$ 413$ Tr. por.), započítania väzby a trestu ( $\$ 414$ Tr. por.), ale predovšetkým aj procesné podmienky premeny zvyšku trestu odňatia slobody na trest domáceho väzenia (§ 414 a Tr. por.), ako aj podmienky podmienečného prepustenia $\mathrm{z}$ výkonu trestu odňatia slobody $(\S 415 \mathrm{a}$ nasl. Tr. por.). Zároveň Trestný poriadok obsahuje blanketné ustanovenie $\S 407$ ods. 1 , ktoré expressis verbis odkazuje na osobitný zákon, predmetom ktorého je úprava podmienok spôsobu výkonu trestu odňatia slobody.

V Slovenskej republike takým osobitným zákonom je zákon č. 475/2005 Z.z.o výkone trestu odňatia slobody, $\mathrm{v}$ znení neskorších predpisov. Vykonávacím predpisom k predmetnému zákonu o výkone trestu odňatia slobody, je vyhláška Ministerstva spravodlivosti SR č. 368/2008 Z.z., ktorou sa vydáva Poriadok výkonu trestu odn̆atia slobody, $v$ znení neskorších predpisov.

Na označenú normatívnu úpravu (všeobecne záväznú), ideovo a vecne nadväzuje interný normatívny akt: Rozkaz ministra spravodlivosti SR č. 15/2018, ktorým sa mení a dopĺn̆a Rozkaz ministra spravodlivosti (d'alej len ako „RMS) č. 16/2015 o zaobchádzaní s obvinenými a odsúdenými.

$\mathrm{V}$ tejto súvislosti sa žiada poznamenat', že normatívna reglementácia úpravy podmienok výkonu trestu odn̆atia slobody v Slovenskej republike, na rozdiel od Českej republiky, neobsahuje v osobitnom zákone č. 475/2005 Z.z. o výkone trestu odňatia slobody, generálnu kompetenčnú klauzulu, ktorá by legislatívno-technicky, vytvorila normatívny rámec (podmienky) vstupu súkromného sektora do prevádzky a správy štátnych Ústavov na výkon trestu odñatia slobody, teda na privatizáciu väzenského systému.

\section{Záver}

Privatizácia väzenského systému je predmetom pomerne zanietenej diskusie trestnoprávnej jurisprudencie, ale rovnako tak zástupcov z netrestnej oblasti a dokonca aj širokej verejnosti, a to od polovice 19. storočia, pričom má svojich priaznivcov, ako aj odporcov, ktorých argumentácia je častokrát skôr emotívna, ako racionálna, ale predovšetkým je motivovaná existujúcimi morálnymi a ideovými dogmami, ktoré vychádzajú zo spoločensko-ekonomických pomerov, tej ktorej krajiny.

Nevyhnutným predpokladom, akejkol'vek kvalifikovanej diskusie o prípadnej privatizácii väzenského systému, ako aj o jej konkrétnej forme - modelu praktického uplatnenia, je samotné poznanie a pochopenie systému a princípov, na ktorých sú jednotlivé modely privatizovaného väzenského systému vybudované. V spoločnosti je totiž historicky dlhodobo budovaná a zakotvená hlboká nedôvera ku všetkému novému, či nepoznanému, aj preto je nevyhnutné na túto tému vyvolat' širokospektrálnu verejnú diskusiu, ktorá by mala vyústit' do konkrétnych aplikačných návrhov - riešení tohto fenomému.

Pravdou je, že prípadná privatizácia väzenského systému, nech by bola implementovaná v akejkol'vek forme, nevyrieši všetky problémy, ktoré sa dlhodobo ku- 
mulovali v existujúcom štátnom väzenskom systéme, avšak nepochybne privatizácia väzenského systému v determinovanej a evolutívnej forme, by mohla napomôct' riešeniu aspoň časti existujúcich problémov väzenského systému. Determinácia privatizácie väzenského systému znamená stanovenie transparentných pravidiel (podmienok) vzájomnej spolupráce medzi štátom a súkromným sektorom, a to tak v oblasti právnej, ekonomickej, ako aj penitenciárnej. Predmetom právnej regulácie, by mala byt' už samotná možnost' zriadenia väznice $\mathrm{v}$ inom objekte ako je objekt $\mathrm{v}$ správe Zboru väzenskej a justičnej stráže, pričom rozhodnutie o tom by malo byt' zákonom kompetenčne delegované na Ministra spravodlivosti Slovenskej republiky. Zároveň vo forme zákona, by bolo potrebné vyregulovat', že kompetencie Zboru väzenskej a justičnej stráže, pri realizácii ktorých dochádza k zásahom do základných práv a slobôd odsúdených, by aj nad’alej vykonávali a zodpovedali za ne príslušníci Zboru väzenskej a justičnej stráže. Konkrétne ide o stráženie, dozor, dohl’ad, zaobchádzanie $\mathrm{s}$ väzňami, ako aj dodržiavanie zákonných podmienok výkonu trestu, tak ako sú tieto kompetencie normatívne ukotvené aj de lege lata v $\S 6$ ods. 1 Zákona č. 475/2005 Z.z. v znení neskorších predpisov, o výkone trestu odňatia slobody. Tým by boli stanovené všeobecné normatívne limity pre možné formy (modely) spolupráce medzi štátom a súkromným sektorom pri privatizácii väzenského systému. V konečnom dôsledku obdobným spôsobom je táto „privatizácia“ vyregulovaná aj v Českej republike, a to konkrétne v ust. § 13 zákona č. 169/1999 Sb. O výkone trestu odnětí svobody. Evolutívna privatizácia väzenského systému znamená postupné zavádzanie (implementáciu) jednotlivých prvkov súkromného charakteru do štátneho väzenského systému, a to od jednoduchších foriem spolupráce, ktoré sa osvedčili aj v iných krajinách, a proti ktorým nič zásadné nenamietajú ani inak odporcovia privatizácie väzenského systé$\mathrm{mu}$. V prvej fáze, by teda bolo namieste implementovat model súkromných služieb, predmetom ktorých by bolo zabezpečenie práce pre odsúdených a v prípade, ak by sa tieto formy spolupráce osvedčili, potom, je možné uvažovat' aj o d'alších formátoch (modeloch) spolupráce. Avizované formy (modely) implementácie súkromných prvkov do štátneho väzenského systému, by nepochybne neboli ani v rozpore s morálnymi a ideovými piliermi súčasného väzenského systému, naopak možno dôvodne predpokladat' ich všeobecnú spoločenskú prospešnost'.

\section{Literatúra:}

- CHI, K. S.: Prison Overcrowding and Privation. Models and Opportunites. In: The journal of State Govermment, Mar/Apr, 1989, 62, 2.

- DI LULIO, J.J.: What'swrong with Private Prisons. In: Public Interest, Summer 1988, 92.

- DRGONEC, J.: Ústava Slovenskej republiky, komentár. Šamorín: Heuréka, 2007.

- ESSER, A.: Funchtinswandel strofrechtlicher Prozesmawimen: Auf dem Weg zur „Reprivotisierung" des Strafverfahrens. In: Karl Krocschell recht und Venfahren: Symposium den recht\&swissen schaftlichen Fakultäten der Albert - Ludwigs Universität Osaka, Heidelberg: Müller, 1993.

- FLEGL, V.: Minimální standardní pravidlá pro zacházení s vězněnými osobami. In: Medzinárodni ochrana spravedlnosti a lidskosti (Dokumenty OSN). Praha: SPEKTRUM; 1990. 
- JUNG, Y.: Prison privatization a perspective on core governmental functions. In: Crime, Law and Social Change (2010) 54.

- KARABEC, Z.: Poznámky k trestní politice. In: Kriminalistika č. 1/2012.

- KUČERA, V.: Evropské väzenské systémy. In: Právné rozhledy, 2002, č. 11.

- LA JORNADA: Americký Gulag je výnosný byznys.! První zprávy.cz.(online), 3.10.2019(cit. 2019-10-22). Dostupné na: http://www.prvnizpravy.cz (zpravy) lajornada-americky-gulag-jevynosny-byznys.

- MIKULEC, V. - NOVOTNÝ, O.: Vězentví a právo. In: Veřejná správa a právo: pocta prof. JUDr. Dušanu Hendrychovi k 70. narozeninám. 1. vydání, Praha: C.H.BECK, 1997.

- NAVRÁTIL, P.: Konec nudy ve věznicích? Vězni nastoupí do práce. In: Globe24.cz(online). 20.12.2018 cit. 2019-10-22). Dostupné na : https://globe24. cz.domov(65023-konce-nudy-ve-veznicich-vezni-nastoupi-do-prace.

- OGLE, R., S.: Prison privatization. An Enviromental Cater - 22. In: Justice Quarberly. Vol. 16. No 3 (199).

- PILCHER, D.: State Correctional Industries: ChoosingGoals, Accepting Tredeoffs, Denver, Vo: National Conference of State Legislatures, June 1989.

- ROMŽA, S.: Koncepcia prípravného konania. Brno: Tribun EU, 2010.

- ROMŽA, S.: Význam spoločensko - ekonomických podmienok na formovanie trestnej politiky štátu. In: Trestná politika štátu, história, súčasnost'a perspektívy; Zborník vedeckých príspevkov z Interdisciplinárnej celoštátnej vedeckej konferencie s medzinárodnou účastou. Košice: UPJŠ, 2015.

- SVÁK, J.: Ochrana l’udských práv (z ohl'adu judikatúry a doktríny štrasburských orgánov práv). Bratislava: EURO KÓDEX; 2003.

- ŠRÁMEL, B.: Privatizácia väzenského systému: áno alebo nie? In: Trestné právo, 2015 , č. 1.

- ŠTRKOLEC, M.: Väzenstvo Slovenskej republiky - vybrané problémy súčasnosti a perspektívy do budúcnosti. In: Trestná politika štátu, história, súčasnost'a perspektívy; Zbornik vedeckých príspevkov z Interdisciplinárnej celoštátnej vedeckej konferencie s medzinárodnou účastou, Košice: UPJŠ, 2015.

- TLAPÁK - NAVRÁTILOVÁ, J.: Má privatizace vězeňství budoucnost? In: Kriminologické a organizačno-technické aspekty privatizácie trestného práva, Zbornik príspevkov z medzinárodnej vedeckej konferencie III. Košické dni trestného práva. Košice: UPJŠ, 209.

- VÁLKOVÁ, H. - KUCHTA, J. a kol.: Základy kriminológie a trestní politiky, 2. vydání. Praha: C.H.BECK, 2012.

- ZAGER, M.A. - McGAMA, J. - GARCIA, L.: Prison Privatization and Public Budgeting: A Meta - analysis of the Literature. In: Journal of Public Budgeting Accounting and Financial Managment, Summer 2001, 13, 2.

- II. ÚS 100/02. Nález z 30. januára 2003. Zbierka nálezov a uznesení Ústavného súdu Slovenskej republiky 2003 - I. polrok. s. 65.

- http://www.zvjs.sk/dokumnety/rocenky/Rocenka2019.

- http://www.rokovania.sk/File.aspx/ViewDocumentHtm/MaterDokum 175978?prefixFile.

- http://www.rokovania.sk/Rokovania.aspx/BodRokovaniaDetail?id Materiál=22614. 
Summary: Limits and Perspectives of Imprisonment for Adult Convicts, in Private Institutions for Serving the Imprisonment in the Slovak Republic, with Regard to Legal and non-Legal Guarantees of Legality

A necessary precondition for any qualified discussion about the possibility of privatization the prison system, as well as its specific form - the model of practical application, is the knowledge and understanding of the system and the principles on which the individual models of the privatized prison system are built. The society has historically built and deepened a deep distrust of everything new or unknown, which is why it is necessary to provoke a broad-based public debate on this topic, which should result in specific application proposals - solutions to this phenomenon.

It is true that the possibility of privatization the prison system, in whatever form, will not solve all the problems that have long accumulated in the existing state prison system, but undoubtedly the privatization of the prison system in a determined and evolutionary form could help solve at least part of the existing problemsn of prison system

prof. JUDr. Sergej ROMŽA, PhD.

Univerzita Pavla Jozefa Šafárika Právnická fakulta, Katedra trestného práva

Kováčska ul. č. 26 04175 Košice Slovenská republika sergej.romza@upjs.sk 